\title{
Implementation of Criminal Sanctions by Public Prosecutor against Narcotics Abuse
}

\author{
Prihananto * and Anis Mashdurohatun**) \\ *) Student of Master of Law, Faculty of Law, Universitas Islam Sultan Agung \\ (UNISSULA) Semarang, E-mail: antox.hoed@gmail.com \\ ${ }^{* *}$ Faculty of Law, Universitas Islam Sultan Agung (UNISSULA) Semarang
}

\begin{abstract}
The purpose of this study is to describe and analyze the implementation, barriers and policies to overcome obstacles in the application of criminal sanctions by public prosecutors in prosecuting class I narcotics abusers at the Semarang City District Attorney. The method used in this research is juridical empirical, which is descriptive-analytical. The data used in this study are primary data and secondary data, which were obtained from interviews and literature studies, then analyzed qualitatively. The conclusions in this study are: (1) the application of criminal sanctions by the public prosecutor refers to the BAP and evidence provided by the police, which is based on the activities of the suspect when the police are arrested; (2) obstacles in the implementation of the application of criminal sanctions by the public prosecutor, including obstacles in terms of legal substance, legal structure and legal culture: (3) so that policies are needed to overcome these obstacles to achieve justice, including revision of articles in the Law. Narcotics Law, holding knowledge sharing, holding outreach, and coordinating with related agencies.

Keywords: Prosecutor; Justice; Sanctions, Narcotics.
\end{abstract}

\section{Introduction}

The Unitary State of the Republic of Indonesia is a constitutional state. This is as stipulated in Article 1 paragraph (3) of the 1945 Constitution of the Republic of Indonesia which states that: "The State of Indonesia is a constitutional state".

A rule of law is a state that enforces the law optimally, upholds human rights and guarantees citizens equal position in the law and the government is obliged to uphold the law and government without exception, law enforcement is one of the parameters in the country of law. ${ }^{1}$

Indonesia is a rule of law, one of which is to protect humanity. Humanity itself is one of the precepts in Pancasila, namely the Second Principle of Pancasila, which is also interrelated with other principles in Pancasila.

One of the cases that endanger the human values of the Indonesian people is the danger of drugs (Narcotics and Dangerous Drugs). Traditionally and modern, narcotics are widely used for medical purposes. ${ }^{2}$ However, with the times, it has now spread in an increasingly broad spectrum. Not only for medicinal purposes, drugs are now widely used as a profitable business area.

The misuse of narcotics, in fact, is a criminal act, so that against the perpetrator, it is appropriate to carry out a legal process as appropriate to law

\footnotetext{
1 Sri Endah Wahyuningsih and Rismato, January-April 2015, Criminal Law Enforcement Policies Against Money Laundering in the Context of Criminal Law Reform in Indonesia, Journal of Legal Reform, Vol. II No. 1, Faculty of Law, Sultan Agung Islamic University, Semarang, p. 46-47.

2 Laoly, Yasonna H. (2019). Jerat Mematikan, Perspektif Kesejahteraan Ekonomi Dalam Penyalahgunaan Narkotika, Print. 1. Ciputat Tangerang: Pustaka Alvabet. p.25
} 
enforcement in other criminal cases. Misuse of narcotics includes the qualification of a criminal act (delict) as regulated in statutory regulations. ${ }^{3}$

The issuance of regulations on the prevention of narcotics in Indonesia, namely Law 35 of 2009 concerning Narcotics, has become the basis for law enforcers to tackle and eradicate narcotics crimes that endanger human values. The abuse of narcotics brings massive negative impacts, both physical and economic losses and disrupting social life. Most types of narcotics that are abused are Class I narcotics. Elucidation of Article 6 of Act No. 35 of 2009 describes Narcotics Category I are narcotics that can only be used for the purpose of developing science and are not used in therapy, and have a very high potential to result in dependency. ${ }^{4}$

Determination of criminal sanctions for narcotics abusers occupies an important position, because it greatly determines the future of the perpetrator. It is not uncommon for the same case in the narcotics abuse Group I, the perpetrator is subject to different sanctions, which can be in the form of criminal sanctions or sanctions in the form of rehabilitation. Recognition of the equality of criminal sanctions and sanctions for action is a fundamental essence or the basic idea of the double track system concept, 5 which this system is adhered to by Act No. 35 of 2009.

Every person who has violated and disobeyed the law should be punished to provide a deterrent effect, so that he does not repeat the act, as is the case with narcotics abusers, because obeying the law is an obligation for the creation of security and order. 6

Law enforcement aims to obey the law. Community obedience to the law is caused by 3 (three) things, namely: ${ }^{7}$

- Fear of sinning;

- Fear because the power of the ruler is related to the imperative nature of the law;

- Fear of being ashamed of doing evil. Law enforcement by means of non penal means has goals and objectives for internalization purposes.

According to Soerjono Soekanto, conceptually the core and meaning of law enforcement lies in the activity of harmonizing the relationship of values that are outlined in solid rules and embodying the attitude of action as a series of final stage value descriptions, to create, maintain and maintain social peace of life. ${ }^{8}$

One of the most important stages in law enforcement in the crime of narcotics is the stage of prosecution by the public prosecutor. The success in proving and

\footnotetext{
${ }^{3}$ Fadhli, Aulia \& Napza. (2018). Ancaman, Bahaya, Regulasi dan Solusi Penanggulanga-nnya. print. 1. Yogyakarta: Gava Media. p.11-12

4 WP, Ratna. (2017). Aspek Pidana Penyalahgunaan Narkotika, Rehabilitasi Versus Pen-jara (Menyoroti Pasal 127 UU No. 35 Tahun 2009) print.1. Yogyakarta: Legality. p.45-47

${ }^{5}$ Arief, Barda Nawawi. (2011). Kebijakan Hukum Pidana. Jakarta: Prenada Media. p.46

${ }^{6}$ Arsyad, Jawade Hafidz \& Dian Karisma. (2018) Sentralisasi Birokrasi Pengadaan Barang \& Jasa Pemerintah. print.1. Jakarta: Sinar Grafika. p.23

${ }^{7}$ Sri Endah and Indah Lestari, September 2017, Criminal Law Enforcement Against Drug Users at the Central Java Regional Police, Khaira Ummah Legal Journal, Vol. 12. No. 3, Faculty of Law, Sultan Agung Islamic University, Semarang, p. 602.

${ }^{8}$ Soekanto, Soerjono. (2016). Faktor-faktor yang Mempengaruhi Penegakan Hukum. Jakarta: Raja Grafindo Persada. p.5
} 
prosecuting the public prosecutor in cases of narcotics abuse will make it easier for judges to give the fairest possible decision.

\section{Research Methods}

The type of research used in this research is juridical empirical, which is research conducted to analyze the extent to which a regulation or legislation is effective. This research is descriptive analysis because the researcher wishes to describe or explain the subject and object of the research, which is then analyzed and conclusions drawn from the research results. ${ }^{9}$ Analytical in nature, meaning that it does not merely explain, but also describes and analyzes the content and structure of the applicable positive law. ${ }^{10}$ The data used in this study are primary data and secondary data. Primary data were obtained through interviews and secondary data were obtained through literature studies, then analyzed qualitatively.

\section{Results and Discussion}

\subsection{Implementation of the application of criminal sanctions by public prosecutors in prosecuting class I narcotics abusers at the Semarang City District Attorney}

One of the important processes in criminal justice is prosecution by the public prosecutor in applying criminal sanctions in his letter of demand. In imposing criminal sanctions, the perpetrators of criminal narcotics have different roles, positions, and sanctions, both based on the laws and regulations that govern them, and based on the roles and impacts that result from their actions. Criminal sanctions in Act No. 35 of 2009 are regulated in Article 111-148.11

Justice is always upheld in every criminal case that occurs in society, including in narcotics crime cases. Justice is a condition in which a person or community gets what is due to him or their rights. ${ }^{12}$ Justice can only be understood if it is positioned as a condition which the law intends to manifest. ${ }^{13}$ The forms of criminal sanctions that can be imposed on the perpetrators of criminal acts proven in court can be in the form of imprisonment, fines and rehabilitation.

The public prosecutor applies criminal sanctions and actions based on the investigation report and evidence provided by the Police, especially when the

\footnotetext{
${ }^{9}$ ND, Mukti Fajar \& Yulianto Achmad. (2010). Dualisme Penelitian Hukum Normatif dan Empiris. Yogyakarta: Student Library. p.183

${ }^{10}$ Nasution, Bahder Johan. (2016). Metode Penelitian Ilmu Hukum. print.2. Bandung: Mandar Maju. p.91

11Dahlan. (2017). Problematika Keadilan Dalam Penerapan Pidana Terhadap Penyalah-guna Narkotika. Print.1. Yogyakarta: Deepublish. p.62-63

12Tridiatno, Yoachim Agus. (2015). Keadilan Restoratif. Print.1. Yogyakarta: Cahaya Atma Pustaka. p.10

${ }^{13}$ Busroh, Firman Freaddy. (2016). Teknik Perundang-Undangan (Suatu Pengantar). Jakarta: Cintya Press. p.45-46
} 
suspect/defendant is engaged in activities in narcotics abuse. This is done to eradicate the illicit trafficking of narcotics by acting as narcotics abusers. ${ }^{14}$

Every imposition of criminal sanctions must be able to provide benefits for the perpetrator of a criminal act personally, namely that it can correct the wrongdoer of the perpetrator and make the perpetrator not repeat his actions again, as well as for the community in general is security and order.

Seen from the aspect of improving the perpetrator, the measure of effectiveness lies in the aspect of special prevention of crime. So, the measure lies in the problem of how far the criminal (imprisonment) has an influence on the perpetrator or convict. There are two aspects of the effect of the crime on the convicted convict, namely the deferent aspect and the reformative aspect. ${ }^{15}$

Determination of sanctions against narcotics addicts by the public prosecutor, whether to apply criminal sanctions or sanctions, the determination is based on certain considerations, although in the end the verdict rests with the judge.

\subsection{Obstacles in the implementation of the implementation of criminal sanctions by public prosecutors in prosecuting class I narcotics abusers at the Semarang City District Attorney}

There are obstacles in the implementation of the implementation of criminal sanctions by public prosecutors in the prosecution of class I narcotics abusers at the Semarang City District Attorney, which can be seen from:

\subsubsection{In terms of legal substance; 16}

- Drug users are victims or perpetrators;

- One of the problems of Act No. 35 of 2009 is related to the position of narcotics users as perpetrators or as victims. It is difficult to separate between abusers and narcotics trafficking, but these cannot be equated and efforts to overcome them must also be distinguished.

- The implementation of Act No. 35 of 2009 depends on the implementing regulations;

- The absence of visible efforts to formulate implementing regulations from Act No. 35 of 2009, especially for the benefit of users, creates problems because eradication efforts run faster than prevention and recovery efforts.

- The overlapping articles on the punishment of narcotics users;

- Act No. 35 of 2009 does not provide a clear distinction between criminal offenses in Article 127 and other criminal offenses contained in Act No. 35 of 2009. In practice, law enforcement official associate (including/juncto) the criminal offense of the user. narcotics with a criminal offense of possession, possession, storage or purchase of narcotics without rights and against the law where the

\footnotetext{
${ }^{14}$ Steven Lazarus, SH, Interview, as the Public Prosecutor at the Semarang City District Attorney, on July 21, 2020.

${ }^{15}$ Sutrisno, Dawud Budi. (2012). Pengaturan \& Penerapan Hukum Pidana Narkoba. Surakarta: Yuma Pustaka. p.54

16 Dahlan, op.cit., P. 93-99.
} 
penalty is more than 5 years in prison and in some provisions exceeding 9 years in prison.

- There is no clear expiration date for narcotics users.

- The unregulated exclusion of time periods for narcotics users who are or are already in the stage of ex-narcotics users has resulted in law enforcement officials that determine the user as a wanted list for people to supervise drug users where it is not closed in rehabilitation places.

\subsubsection{In terms of legal structure; ${ }^{17}$}

Lack of coordination between public prosecutors and investigators as well as differences in perceptions between law enforcers are obstacles in the preparation of indictments and indictments against class I narcotics abusers. to investigators, making it a waste of time and ineffective.

\subsubsection{In terms of legal culture/culture. ${ }^{18}$}

Lack of legal awareness for the community is what causes the eradication of criminal acts of narcotics abuse to become stagnant, even if it does not go as expected.

\subsection{Policies in overcoming obstacles in the application of criminal sanctions by public prosecutors in prosecuting class I narcotics abusers at the Semarang City Public Prosecutor's Office are to achieve justice}

\subsubsection{Legal substance;}

- Drug users are victims or perpetrators;

It is necessary to carry out a legal reconstruction of Articles 111 and 112 of Act No. 35 Year 2009 which use the words "control, keep, possess" which allows every drug abuser to be entangled with the provisions of the two Articles, as well as the unclear provisions of Article 127 of Act No. 35 of 2009 regarding what conditions and criteria a person can be said to be a narcotics abuser.

- The implementation of Act No. 35 of 2009 depends on the implementing regulations;

Efforts are needed to formulate implementing regulations from Act No. 35 of 2009 , especially for the benefit of users who cause problems because eradication efforts run faster than prevention and recovery efforts.

- The overlapping articles on the punishment of narcotics users;

It is necessary to change the norming related to the expired provisions for narcotics users, so that narcotics users are not subject to punishment for past acts.

\subsubsection{Legal structure; ${ }^{19}$}

Lack of coordination between public prosecutors and other law enforcers as

\footnotetext{
${ }^{17}$ Interview with Steven Lazarus, SH, as public prosecutor at the Semarang City District Attorney, on July 21, 2020.

18Ibid.

${ }^{19}$ Ibid.
} 
well as differences in perceptions among law enforcers, the efforts required are:

- It is necessary to make an MoU (Memorandum of Understanding) and an MoA (Memorandum of Agreement) in cooperation between law enforcers;

- The Semarang City Public Prosecutor's Office has made a policy for handling narcotics crimes by sharing knowledge between law enforcers to get a unity of perception in handling narcotics crime cases, related to the application of criminal sanctions and efforts to catch abusers and narcotics traffickers;

- Law enforcers need to understand jurisprudence or provisions related to narcotics abuse, such as the enactment of SEMA Number 04 of 2010;

- It is very important to conduct a case degree by presenting experts;

- Increase the expertise of information technology (IT) knowledge for prosecutors and other law enforcers;

- Coordinating with airports and ports to anticipate the illicit trafficking of narcotics sent by expedition.

\subsubsection{Legal culture ${ }^{20}$}

It is necessary to socialize about the dangers of narcotics with the help and cooperation of local community leaders, NGOs, the Health Office, and so on. In addition, it is also necessary to include knowledge about narcotics and illegal drugs in the educational curriculum, both at the elementary school to higher education levels.

The values of justice that are to be realized in law enforcement, both in legal substance, legal structure and legal culture are the values of justice in accordance with the principles of Pancasila. Because Pancasila is not only the basic norm, but also the nation's outlook on life, the nation's ideology, and contains the noble values of the Indonesian nation.

Pancasila is able to provide answers to these problems. Pancasila is able to provide the values of justice as a legal reform in Indonesia. Legal reform in Indonesia is very much needed because there are still many new problems that cannot be reached by law. ${ }^{21}$

Justice based on Pancasila prioritizes human rights and equal protection before the law in its realization as the principles of forming a law based on Pancasila. Thus, law enforcers ranging from investigators, the National Narcotics Agency, public prosecutors and judges must understand and be able to take the policy that narcotics abusers are victims and sick people who need treatment so that they are not suitable for imprisonment. The imposition of imprisonment is a futile act in which the state will also experience great losses and especially the victims will suffer more losses.

\section{Conclusion}

Obstacles in implementing criminal sanctions by public prosecutors in prosecuting class I narcotics abusers at the Semarang City District Prosecutor's

\footnotetext{
${ }^{20}$ Ibid.

${ }^{21}$ Febriansyah, Ferry Irawan. (2016), Keadilan Berdasarkan Pancasila (Dasar Filosofis dan Ideologis Bangsa), print.1. Yogyakarta: Deepublish. p.148
} 
Office can be seen in terms of: (a) legal substance: (i) the position of narcotics users as perpetrators or victims in the Narcotics Law, (ii) implementation of the Narcotics Law depends on implementing regulations, (iii) overlapping articles of punishment for narcotics users, and (iv) no clear expiration date for narcotics users, (b) legal structure: lack of coordination between public prosecutors and investigators as well as differences in the perceptions of law enforcers in the handling and application of criminal sanctions for narcotics abusers, and (c) legal culture/culture: lack of legal awareness for the community.

\section{References}

Journal:

[1] Sri Endah Wahyuningsih and Rismato, January-April 2015, Criminal Law Enforcement Policies Against Money Laundering in the Context of Criminal Law Reform in Indonesia, Journal of Legal Reform, Vol. II No. 1, Faculty of Law, Sultan Agung Islamic University, Semarang

[2] Sri Endah and Indah Lestari, September 2017, Criminal Law Enforcement Against Drug Users at the Central Java Regional Police, Khaira Ummah Legal Journal, Vol 12. No. 3, Faculty of Law, Sultan Agung Islamic University, Semarang

\section{Books:}

[1] Arief, Barda Nawawi. (2011). Kebijakan Hukum Pidana. Jakarta: Prenada Media

[2] Arsyad, Jawade Hafidz \& Dian Karisma. (2018) Sentralisasi Birokrasi Pengadaan Barang \& Jasa Pemerintah. print.1. Jakarta: Sinar Grafika

[3] Busroh, Firman Freaddy. (2016). Teknik Perundang-Undangan (Suatu Pengantar). Jakarta: Cintya Press

[4] Dahlan. (2017). Problematika Keadilan Dalam Penerapan Pidana Terhadap Penyalah-guna Narkotika. Print.1. Yogyakarta: Deepublish

[5] Fadhli, Aulia \& Napza. (2018). Ancaman, Bahaya, Regulasi dan Solusi Penanggulanga-nnya. print. 1. Yogyakarta: Gava Media

[6] Febriansyah, Ferry Irawan. (2016), Keadilan Berdasarkan Pancasila (Dasar Filosofis dan Ideologis Bangsa), print.1. Yogyakarta: Deepublish

[7] Laoly, Yasonna H. (2019). Jerat Mematikan, Perspektif Kesejahteraan Ekonomi Dalam Penyalahgunaan Narkotika, Print. 1. Ciputat Tangerang: Pustaka Alvabet

[8] Nasution, Bahder Johan. (2016). Metode Penelitian Ilmu Hukum. print.2. Bandung: Mandar Maju

[9] ND, Mukti Fajar \& Yulianto Achmad. (2010). Dualisme Penelitian Hukum Normatif dan Empiris. Yogyakarta: Student Library

[10] Soekanto, Soerjono. (2016). Faktor-faktor yang Mempengaruhi Penegakan Hukum. Jakarta: Raja Grafindo Persada

[11] Sutrisno, Dawud Budi. (2012). Pengaturan \& Penerapan Hukum Pidana Narkoba. Surakarta: Yuma Pustaka

[12] Tridiatno, Yoachim Agus. (2015). Keadilan Restoratif. Print.1. Yogyakarta: Cahaya Atma Pustaka 
[13] WP, Ratna. (2017). Aspek Pidana Penyalahgunaan Narkotika, Rehabilitasi Versus Penjara (Menyoroti Pasal 127 UU No. 35 Tahun 2009) print.1. Yogyakarta: Legality

Interview:

[1] Interview with Steven Lazarus, $\mathrm{SH}$, as public prosecutor at the Semarang City District Attorney, on July 21, 2020. 